\title{
Road Safety in Dhaka: Challenge for Sustainable Development
}

\author{
Shadika Haque Monia \\ Britannia University, Bangladesh
}

\begin{abstract}
Road safety refers to the idea of methods and solutions to protect road users from being injured or killed in road accidents. Road users include pedestrians, cyclists, rickshaw and van drivers, and riders of public transport systems such as buses, trams, etc. According to the World Health Organization, more than one million people die in road accidents every year and about 50 million people are injured. Road accidents are identified as one of the major obstacles to sustainable development in Bangladesh. In developing countries such as Bangladesh Road, Safety is much lower in developing or underdeveloped countries and the rate of casualties in road accidents is much higher than in developed countries. The scenario is getting serious day by day. Therefore, Dhaka City has been witnessing tremendous growth in population and physical expansion. This study uses the qualitative research theory and the idea of sustainable development as analytical tools. The research was conducted to analyze and discuss road safety in Dhaka. The research method used in the research is descriptive qualitative research with various primary and secondary sources of the studies. This research resulted in the various aspects of road safety in Bangladesh. The differences between theory and practice, domestic legal arrangements as well judicial decisions.
\end{abstract}

Keywords: Road; Safety; Dhaka; Bangladesh; Traffic

This is an open access article under the CC-BY-NC license.

\section{INTRODUCTION}

Bangladesh confronts extreme traffic congestion levels with resulting traffic accidents and health problems for those who live in the city areas. Potential alleviation of these problems lies in the progressive closure of Bangladesh's major cities' sections to motorized traffic to prioritize rickshaws in many ways. The road transport system in Bangladesh is chaotic and accident-prone, mainly visible in the transport system and services of the capital Dhaka. Urbanization in the city is essentially a process of migration from rura1 and smaller towns. Though planning has been initiated to regulate and control the development, the application and execution of the proposed policies are not worth mentioning. Failure of government intervention to guide and direct the land development process is primarily responsible for uncontrolled wetland conversion to urban use. Another problem is that if a city does not grow according to a guideline, the whole system will collapse gradually. Political interference happens everywhere, but here it has descended to the level of greed. The situation is unwanted, but facts for the city's whole and the problem are irreversible. 
A significant number of barriers are interrelated to implement Road Safety Act and judicial decisions as well.

Dhaka ${ }^{1}$ It is the capital of Bangladesh and one of the largest cities in South Asia. Administratively it is the central city in the country. Geographically it is located in a flat area on the north bank of the river Buriganga in central Bangladesh. Dhaka is a megacity and has a population of about 15 million. In terms of people, it is the fourth largest city in South Asia (after Delhi, Karachi, and Mumbai) and the ninth-largest in the world, where almost 115,000 people live in 134 square miles. ${ }^{2}$. Bangladesh Road Transport Corporation (BRTC) mainly operates public buses, and there are some private bus companies and operators as well. Ridesharing services like 'Pathao' 'Uber' have recently become popular in the city. On average, about 400,000 rickshaws run throughout the city every day. ${ }^{3}$ Rickshaws and motorized auto-rickshaws are among the main ways of transportation in Dhaka, which is the highest among all other countries. However, according to official data, a total of 85,000 rickshaws have been registered for Dhaka city. Since 2002, some petrol and diesel-powered vehicles such as baby taxis, tempos have been banned here and replaced by Compressed Natural Gas (CNG) or CNG-powered green auto-rickshaws. As a result, environmental pollution was supposed to be reduced. ${ }^{4}$ Therefore, scooters, taxis, and privately owned vehicles are rapidly gaining popularity among the city's middle-class people. Although the infrastructure of the city is mentionable in the world, traffic congestion and lack of adequate services due to population growth have been increasing every day. ${ }^{5}$ The modernization of the transportation and communication system in recent decades is particularly noteworthy. ${ }^{6} \mathrm{~A}$ high level of operational mismanagement enshrined in the existing transport systems diminishes efficiency and effectiveness in many ways.

1 "The 10 Largest Cities In The World". World Atlas. 20 December 2019. Retrieved 27 March2020.

Dhaka pronounced, formerly known as Dacca, is the capital and the largest city of Bangladesh.

2 "Population \& Housing Census-2011" Bangladesh Bureau of Statistics. p. 41. Archived from the original (PDF) on 8 December 2015. Retrieved 15 December 2015.

\footnotetext{
${ }^{3}$ Hoque, Mazharul, Sohel Mahmud, Arefin Siddiqui, and Chowdhury Kawsar. "Road safety in Bangladesh and some recent advances." In Proceedings of the Road Safety on Four Continents Conference, vol. 14, pp. 12p12p. Conference Sponsor, 2007.

${ }^{4}$ Hoque, Md Mazharul. "The road to road safety: issues and initiatives in Bangladesh." In Regional Health Forum, vol. 8, no. 1, pp. 39-51. 2004.

${ }^{5}$ Hoque, Md Shamsul, Shah Md Muniruzzaman, and S. N. Ahmed. "Performance evaluation of road safety measures: a case study of the dhaka-aricha highway in bangladesh." Transport and communications bulletin for Asia and the Pacific74 (2005): 33-56.

${ }^{6}$ Hoque, M. M., J. Bin Alam, and K. M. N. Habib. "Road safety issues and initiatives in Bangladesh: the context of regional significance." Publication of: ARRB Transport Research, Limited (2003).
} 
SDG $^{7}$ Targets 3.6 and 11.2 require a halving of worldwide road death and all-inclusive access to the safety vehicle in urban areas and settlements separately (United Nations 2015). In 2020, particularly in the absence of insufficient resources and action, the SDG Target 3.6 date for halving global road deaths by 2020 had not to be met. The country has a National Road Safety Strategic Action Plan (NRSSAP) with a target to achieve a reduction of 50 percent road crash fatalities by 2020. (GoB, 2016). ${ }^{8}$ Therefore, at the end of the year 2020, it has raised a big question for the country how much it has fulfilled the National Road Safety Strategic Action Plan (NRSSAP). On the other hand, a significant number of corrective measures have been taken by the regulatory authorities such as RAJUK, DTCA and DMP, including controlling the land-use system, trip generation and distribution. ${ }^{9}$

\section{Research Questions}

1. What are the present legal mechanism of the transport system in Bangladesh?

2. Why Road Safety has become a challenge for sustainable development in Bangladesh?

\section{RESEARCH METHOD}

The research will be a doctrinal based analytical study of the respective subject area. It would be a discussion-based work with the available sources of law relating to the subject matter. It would be based on both primary and secondary sources. The primary sources include various data from government sectors. The secondary sources include books, articles, and review of case laws on this subject matter. Journals and Digital sources will be explored and utilized for this purpose too.

In the first part of the discussion, the first research question will be discussed. This part of discussion tries to analysis present transportation scenario of Dhaka city, regarding the legal protection under the domestic legal system.

In the following part of the discussion, it tries to analyze the second research question. In this part of discussion, it assesses the inherent challenges of ongoing road transport mechanism and to what extent the idea of road safety has become a challenge for sustainable development. To find out the answer of the second research question, the role of Bangladesh judiciary will be analyzed.

Finally, in the concluding remarks, the paper will recapitulate the idea of road safety in the context of present state practice of Bangladesh.

\footnotetext{
${ }^{7}$ The Sustainable Development Goals (SDGs), also known as the Global Goals, were adopted by all United Nations Member States in 2015 as a universal call to action to end poverty, protect the planet and ensure that all people enjoy peace and prosperity by 2030 .

${ }^{8}$ Hoque, M. M., S. Hossain, S. Islam, and M. A. Rahman. "Safe system for sustainable pedestrian safety in Bangladesh." In Australasian Road Safety Research Policing Education Conference, 2013, Brisbane, Queensland, Australia. 2013.

9 Hoque, M., \& Salehin, M. F. (2013). Vulnerable Road Users (Vrus) Safety in Bangladesh. In 16th International Conference Road Safety on Four Continents. Beijing, China (RS4C 2013). 15-17 May 2013. Statens väg-och transport for skningsinstitut.
} 


\section{FINDINGS AND DISCUSSION}

\section{Road Transport scenario in Dhaka Metropolitan City}

The most common causes of traffic jams in Dhaka are land and transport planning, practical and operational deficiencies, and road networking systems. The number of roads in Dhaka is not more than seven percent of the total area, and experts say a megacity such as Dhaka needs to have at least 30 percent of its wide roads, which implies that only one-third of the required roads are in this city. Besides, the total area of Dhaka city is 1,353 sq km, and the current road area is 2,200 km, of which $210 \mathrm{~km}$ is the main road. ${ }^{10}$ Thus, this is exceptionally clear that roads are substantially less than required.

Conversely, the quantity of vehicles has dramatically increased over the most recent five years. Besides, in any event, 15 percent of the current streets are illicitly involved in various manners. Due to Dhaka's population's rapid growth, the anticipated trip generation every day for the following 20 years' period frame is 159.63 million, which is multiple times higher than the current outing age every day. ${ }^{11}$ For such an enormous city and tremendous travel request, mass travel is essential for its transportation system. ${ }^{12}$ Mass travel of present contribution is just 31 percent of the traveller trips, whereas mass travel should share 80 percent of the total trips to give an effective transportation system. As indicated by a World Bank report, over the most recent ten years, the average traffic speed in Dhaka has dropped from 21 kilometres per hour to 7 kilometres per hour and; most surprisingly, by 2035, the speed may drop to 4 kilometres per hour, which is slower than the walking speed.

Due to Traffic blockage in the city, around 5 million working hours reliably is being killed and costs the country USD 11.4 billion reliably. The budgetary hardship is a tally of the cost of time lost in rush hours and the money spent on working vehicles for the extra hours. ${ }^{13}$ The city-based rail system is under construction in Dhaka, officially known as Mass Rapid Transit (MRT). In 2013, the government formulated a strategic transport plan to reduce the growing traffic congestion and road congestion in the overcrowded city, under which a metro rail was planned to be set up in Dhaka for

\footnotetext{
10 Mahmud, SM Sohel, Md Shamsul Hoque, and Q. A. Shakur. "Road safety research in Bangladesh: constraints and requirements." In The 4th Annual paper meet (APM) and the 1st Civil Engineering Congress, organized by Civil Engineering Division Institution of Engineers, Bangladesh(IEB), Session V: Transportation Engineering-II, pp. 22-24. 2011.
}

${ }^{11}$ Ahsan, H. M., M. A. Raihan, M. S. Rahman, and N. H. Arefin. "Reporting and recording of road traffic accidents in Bangladesh." In 4th annual paper meet and 1st civil engineering congress, pp. 22-24. 2011.

12 Mahmud, S. S., Hoque, M. S., \& Qazi, A. S. (2009). Road safety problems in Bangladesh: some major initiatives, constraints and requirements. Transport and Communications Bulletin for Asia and the Pacific, 79, 61-89.

${ }^{13}$ Report by Brace Institute of Government and Development, Available at: http://www.brac.net/road-safetyprogramme 
the first time. ${ }^{14}$. However, in most cases, unplanned roads, overcrowded parking, corrupted traffic management, and under-construction projects are responsible for increasing traffic across the city. ${ }^{15}$ Although there is a little relief among the people after constructing a few flyovers in the city, they are not bringing many benefits. Even if the car is moving in one place, it gets stuck in another place. The flyovers are also jammed above and below most of the time. Thus the traffic jam in Dhaka is not going to end in a short period. Therefore, the traffic jam in Dhaka is not going to end in a short period. There is no doubt that traffic congestion is an obstacle in the context of Bangladesh, and it can accelerate the country's economic development. Rather transport system will hamper the social, physical-economic growth of the country. 16

From 2015 to July 2018, almost 25,000 people have died, and about 72,000 injured in road accidents. As indicated by the World Health Organization(WHO), nearly 55 individuals are consistently killed in road accidents in Bangladesh. Furthermore, 12,000 individuals are being killed, and 35,000 become injured through road accidents in the country, respectively. Compared to the previous year, the number of road accidents and deaths in Bangladesh increased by 1,599 in 2019, where death has increased by 788.17 In any event, 7,855 individuals were killed and 13,330 others injured in Bangladesh's road accidents over the year 2019. Surprisingly, in 80 percent of road accidents, no case is filed, and in 20 percent of cases, and only 1 percent is convicted.18 Therefore, from 2015 to July 2017, 25,000 people were killed, and about 72,000 injured in road accidents. ${ }^{19}$. According to the Bangladesh Road Transport Authority (BRTA), the number of registered vehicles in the country in 2016 was only 35 lakh 42 thousand. Still, the number of valid licensed drivers is 26 lakh 40 thousand. In other words, about 9 lakh vehicles are driven by unlicensed drivers. Besides, the number of unfit cars in the country is four lakhs 99 thousand. Due to these reasons, road accidents continue to increase and take proper measures to forestall accidents just as new road transport laws have become the demand of the time

\footnotetext{
${ }^{14}$ Hoque, M., Smith, G., \& Mahmud, S. M. (2011). Safer roads in Bangladesh: addressing the challenges of road infrastructure safety and linear settlements. In 24th World Road Congress World Road Association (PIARC).

${ }^{15}$ Ahmed, Bayes. "Contemporary issues and priorities in addressing the road safety problems of Dhaka metropolitan area, Bangladesh." Journal of Bangladesh Institute of Planners 6 (2013): 103-118.

${ }^{16}$ Hoque, M. M. "Road planning and engineering for promoting pedestrian safety in Bangladesh." In ROAD ENGINEERING ASSOCIATION OF ASIA AND AUSTRALASIA (REAAA) CONFERENCE, 10TH, 2000, TOKYO, JAPAN. 2000.
}

${ }^{17}$ Biswas, S. K. "Road Traffic Injuries: An Emerging Problem in Bangladesh." Faridpur Medical College Journal 7, no. 1 (2012): 5-5.

${ }^{18}$ Mannan, Mohammed Shafiqul. "Road accidents in metropolitan Dhaka, Bangladesh." IATSS research 23, no. 2 (1999).

${ }^{19}$ According to a study by the Bangladesh University of Engineering, 53\% of these road accidents occur due to speeding, $36 \%$ due to reckless behaviour of the driver, and the remaining $10 \%$ due to vehicle defects and environment. 
On 29 July 2018, students took to the streets claiming road safety after two college students were killed in a reckless bus crash on Dhaka's airport road. After the movement, the Gazette of the new Road Transport Act, 2018 was published. ${ }^{20}$ The Department of Roads and Highways of the Ministry of Road Transport and Bridges, in a 2016-17 survey, claimed that a fatal road accident caused an economic loss of about TK 50 lakh. ${ }^{21}$ The result has determined complete financial loss, medical expenses, cost of living, loss of vehicle and administrative and all other accounts of a working person who was the victim of an accident (8 October, 2018) was passed in the parliament in September same year. ${ }^{22}$ The new law is being repealed through the implementation of the Motor Vehicles Ordinance 1983. But, it is critical to executing the Road Transport Act to decrease road accident. As long as the rules are not in place, the Motor Vehicles Rules, 1983 will remain in force. At this point, the question arises without having new rules, and the new Act can not be a success to some extents. ${ }^{23}$

The new law has expanded a wide range of punishments, such as disregarding traffic signals, ${ }^{24}$ non fastened the seatbelt and using a mobile phone while driving, injuring someone while driving recklessly 25 . In addition to, inability to show the fare chart on public transport, and collecting additional fare ${ }^{26}$ illegally changing the meter of contract carriage ${ }^{27}$, working as a conductor in any public transport without a conductor's license ${ }^{28}$ operating motor vehicle without ${ }^{29}$, using false or fake Registration number ${ }^{30}$ and operating a vehicle without a fitness certificate or using expired fitness certificate or passing economic life or unsuitable for fitness or operating a risky motor vehicle are also punishable offences under the same $\mathrm{Act}^{31}$. Interestingly, under the provision of new law', to get a driving license, it is required that the diver have to complete minimum eighth-grade education, and an assistant must be pass fifth-grade education. A valid license will carry 12 points where nine types of traffic violations will deduct a point. If it

\footnotetext{
${ }^{20}$ Wikipedia, Students end protests on road safety in Bangladesh after nine days; education ministry to hold meet tomorrow". First post. 7 August 2018. Retrieved 9 August 2018.

${ }^{21}$ Hosain Zakir, 'How can we fix the world's worst traffic?' Dhaka tribune, 23, May,2019,Avaiable at: https://www.dhakatribune.com/opinion/op-ed/2019/05/23/how-can-we-fix-the-world-s-worst-traffic,
}

${ }^{22}$ A.A.Haider, Traffic jam: The ugly side of Dhaka's development The Daily Star,May,13,2018, Avaiable At:- $\quad$ https://www.thedailystar.net/opinion/society/traffic-jam-the-ugly-side-dhakas-development$\underline{1575355}$

${ }^{23}$ Mamun Sohel, Road Transport Act, 2018 goes into effect on Friday: BRTA not yet prepared to implement new traffic law, November, 1, 2019 Avaiable At:https://www.dhakatribune.com/bangladesh/2019/11/01/road-transport-act-2018-goes-into-effect-onfriday-brta-not-yet-prepared-to-implement-new-traffic-law

${ }^{24}$ The Road Transport Act, 2018, Section-85,

${ }^{25}$ ibid, Sction- 75 .

${ }^{26}$ Ibid, Section 80

${ }^{27}$ Ibid, Section, 35 ,

${ }^{28}$ Ibid, Section, 14 ,

${ }^{29}$ Ibid, Section, 16

${ }^{30}$ Ibid, Section, $16 \& 72$.

${ }^{31}$ Ibid, Section, 25 .

| 77 
reaches 12 points, the license will be revoked..$^{32}$ Delivering an appointment letter has been made compulsory for the driver and his assistant. ${ }^{33}$. Besides, driving vehicles without Tax-Token or using expired Tax-Tokens without route permits is also a punishable offence. (s.26 \& 28) Interestingly, updating fines with a few more zeroes behind the fines of the previous Act has drawn the general mass's attention, which creates uncertainty regarding proper implementation. For his reason, some assume the enforcement of the new law will be very selectively. ${ }^{34}$

There could be some problems in law enforcement at first and will be balanced gradually. Although the Road Transport Act was enacted in 2018, the government has implemented it next year as several complaints were recorded from transport owners and workers. The law enforcement agencies themselves, the public and transport drivers, helpers, or pedestrians, have no unique idea about the Act ${ }^{35}$. As most of the devices and the relevant document have not yet updated with the new Acts, law enforcement agencies cannot impose any spot fines. On the other hand, the new law was not organized in the Mobile Court Act's schedule, 2009 by the legislators; thus, the mobile court run by the BRTA could not step in. Although the law has come into force, the authorities were not well prepared with modern equipment and trained human power. 36

Without proper implementation of the Road Transport Act 2018, it won't be assumed any extraordinary role in lessening road accidents. It is important to be increasingly vocal in regard, and legal action ought to be made. ${ }^{37}$ This law isn't for imprisonment or imposing fines rather than reestablished discipline in the road. Therefore, if everybody complies with the law, road safety will be ensured. Accelerated implementation of the law, ensuring public awareness, should also be encouraged. Road defects need to be fixed soon, and educational institutions can become aware of the students to obey road safety rules. Although the new road transport law has come into force, the old law will be applied. The new law will be implemented at a tolerable level in phases. Before that, the enforcement agencies will have to gain detailed information about the law, especially pedestrians and drivers.

\footnotetext{
${ }^{32}$ Ibid, Section-70

33 ibid, Section-5,

${ }^{34}$ BRTA chairman in the context of the new law. Md. Kamrul Ahsan said, the purpose of the law is not to punish, but to establish discipline in the road. Mamun Sohel, Road Transport Act, 2018 goes into effect on Friday: BRTA not yet prepared to implement new traffic law, November, 1, 2019 Avaiable At:https://www.dhakatribune.com/bangladesh/2019/11/01/road-transport-act-2018-goes-into-effect-onfriday-brta-not-yet-prepared-to-implement-new-traffic-law
}

${ }^{35}$ Bangladesh enforcing much-awaited road safety law from Nov 1, 23 October, 2019, https://bdnews24.com/bangladesh/2019/10/23/bangladesh-enforcing-much-awaited-road-safety-law-fromnov-1

${ }^{36}$ A.H.Rahbar, road Transport Act 2018 - details, repercussions, reactions, The Daily Star, November, 6, 2019, Avaiable At:- $\quad$ https://www.thedailystar.net/shift/news/road-transport-act-2018-details-repurcussions$\underline{\text { reactions- } 1823818}$

37 N.F.Antara, Why can't we stop traffic accidents in Dhaka? 10 June, 2018, Available at: https://www.dhakatribune.com/bangladesh/dhaka/2018/06/10/why-can-t-we-stop-traffic-accidentsin-dhaka 


\section{Rethinking the Role of Judiciary in Road Safety}

In Bangladesh, 80 percent of victims of road accident do not file a case. According to an organization working on road passengers' rights, victims are less likely to seek legal redress due to fears of transport owners and workers' organizations and delays in litigation. ${ }^{38}$ Experts are also concerned about the proper implementation of the law in the case of one death after another in a chaotic competition of buses on the streets of Dhaka. ${ }^{39}$ According to them, no governmental agency is taking responsibility for the anarchy in the streets, which is also a matter of great concern. Although several reports have been recording every day in road accidents, one or two are seen to be on trial after a long time. 40

On the one hand, weak traffic regulation and lax enforcement are also responsible for the same. Therefore, transport owners and workers' organizations are influential and ordinary passengers do not dare to take any action against them and not even interested in seeking justice. Almost eighty percent of road accidents are being settled through compromises, and in 99 percent of the cases the accused get punishment. Due to which no one is interested in filing a case of those twenty percent of the cases. ${ }^{41}$

In the point of Road safety, the role of judicial decisions is praiseworthy to some extent but much frustrating in the execution of judgment accordingly. Historically, very few compensation cases were filed, but this rate is increasing gradually. Within the last few years, more than 20 public interest litigation cases were filed in the High Court Division seeking compensation from the families of the injured and the victims of a road accident. ${ }^{42}$ The first case in the country seeking compensation for a road accident occurred 29 years ago and took 26 years to final judgment, although the compensation money has not yet received. Surprisingly, the country's first suit seeking compensation for journalist Mozammel Hossain Montu's road accident occurred 29 years ago. ${ }^{43}$ Fair Justice is closely related to Road Safety. The family of filmmaker Tareq Masood ${ }^{44}$ and journalist Mishuk Munir was also ordered to pay compensation by the insurance company and bus company

\footnotetext{
${ }^{38}$ Mahmud, S. S., Ahmed, I., \& Hoque, M. S. (2014). Road safety problems in Bangladesh: Achievable target and tangible sustainable actions. Jurnal Teknologi, 70(4).

${ }^{39}$ Ishtiaque, Ahmed, and Bayes Ahmed. "Urban road accidents in Dhaka, Bangladesh." (2013).

${ }^{40}$ Rahman, M. "Road accidents in Dhaka, Bangladesh: How to provide safer road?." In Proceedings of the Road Safety on Four Continents Conference, vol. 14, pp. 15p-15p. Conference Sponsor, 2007.

41 Rahman, Sonia. "Development of an accident prediction model for intersections of Dhaka city, Bangladesh." International Journal of Computer Applications 47, no. 16 (2012).

${ }^{42}$ Sufian, Abu Ahmed, Sakib Mahmud Khan, Ishtiak Ahmed, Sababa Islam, and Niloy Saha. "Safety analysis: observed deficiencies in existing transportation system of Bangladesh." International Journal of Urban Planning and Transportation 27, no. 1 (2016).

${ }^{43}$ Bangladesh Beverage Industries Ltd v. Rowshon Akter, 62 DLR (2010)483)

44 Tareque Masud (6 December 1956 - 13 August 2011) was a Bangladeshi independent film ... and was greeted with enthusiasm for its realistic depiction of life without the melodrama that is prevalent in many other South Asian films.
} 
but has not yet implemented it.45. In February 2017, the driver was sentenced to life imprisonment, but compensation did not solve. On 3 December 2017, Division Bench of the High Court Division delivered the judgment of a compensation case ordering payment of Tk4.62 crores to the family of eminent filmmaker Tareque Masud and Misshuk Munir in 2011.46 The claim was brought under the Motor Vehicles Ordinance 1983, and the judgment applied two cases of jurisdiction reported in 22 DLR (SC)(1970) 51 and 69 DLR (AD) 196. And the court applied and developed tort law principles in this case which would undoubtedly be extremely helpful for reference in other tort cases. ${ }^{47}$

It is perhaps the first judgment, thorough which judgment under Article 110 of the Constitution of the People's Republic of Bangladesh has been delivered case. ${ }^{48}$. Within the provision of the same Article, the High Court Division may, without considering the lower courts' importance, conduct its judgments. In the past, two or four rare instances were made in which the Supreme Court intervened directly under Article 110 of the Constitution. None of the cases the victims have had success in compensation cases is covered under Article 110. In the case of compensation, a new precedent has been established within this case. Through considering some specific claim, compensation has been granted in the Catherine Masud case. In ascertaining the proficient possibility deceased, professional respect, and also considering the income tax return. In the time of calculating the damages, the age of retirement was also considered.

Surprisingly, most of the Tort law principles is underdeveloped in Bangladesh and determining the nature of injury and damages become difficult in many cases. ${ }^{49}$ Besides, through 69 DLR (AD) 196 cases, the Appellate Division in 69 DLR (AD) 196 affirms that damages for pain, anguish, enduring and loss of desire forever are convoluted. The standard of assessing the measure of damages in the event of significant carelessness bringing about death must not be objective; however, a target one and respect is to be had to the deceased's profit at the time of his death, future possibilities of life expectancy and so forth. In the case of Bangladesh Beverage Industries Ltd v. Rowshon Akter, the Hon'ble High Court Division, Supreme Court of Bangladesh awarded Taka two crores as compensation based on the above criteria to a journalist's dependents killed in a road

\footnotetext{
45 SAJJAN, MIRA. "Compensations for Death Change in Approach Is Needed In Bangladesh."
}

${ }^{46}$ T.Huda A landmark compensation suit, 5 December, The Daily Star, 2017, Available at:https://www.thedailystar.net/law-our-rights/landmark-compensation-suit-1500478

${ }^{47}$ A.K.Khalid, ASSESSING TORT CLAIMS: Relevance of Catherine Masud case, 31July, 2018, Available at:- https://www.thedailystar.net/law-our-rights/assessing-tort-claims-1613473

${ }^{48}$ Article-110, Transfer of cases from subordinate courts to High Court Division, if the High Court Division is satisfied that a case pending in a court subordinate to it involves a substantial question of law as to the interpretation of this Constitution, or on the point of general public importance, the determination of which is necessary for the disposal of the case, it shall withdraw the case from that court and may -(a) either dispose of the case itself; or(b) determine the question of law and return the case to the court from which it has been so withdrawn (or transfer it to another subordinate court) together with a copy of the judgment of the division on such question, and the court to which the case is so returned or transferred shall, on receipt thereof, proceed to dispose of the case in conformity with such judgment.

${ }^{49}$ Lord Neuberger, 'Some Thoughts on the Principles Governing the Law of Torts'2 November, 2016, Available at:- https://newjurist.com/some-thoughts-on-the-principles-governing-the-law-of-tort.html 
traffic accident in 1989.50 In calculating the quantum, the deceased's salary until retirement. These criteria were first enumerated in the judgment Bangladesh Beverage Industries Ltd v. Rowshon Akter case. The Hon'ble High Court Division, Supreme Court of Bangladesh, the amount of taka two crores was ensured as compensation for the dependents of a journalist killed in a road traffic accident in 1989.

The amount was determined by calculating the salary of the deceased person until retirement. ${ }^{51}$ Therefore, the compensation was for his dependents, wife, and children. The deceased family members have not yet received any amount; they got justice in a black and white form but not in reality. They filed another suit to implement the judgment and to force the defendant to pay. The court finally ordered the beverage company to pay the compensation amount by auctioning off its property at Tejgaon. Unfortunately, the matter is yet to progress..$^{52}$ Even though the High Court ordered Abrar Ahmed Chowdhury, a university student killed in a bus crash in Dhaka's Kuril area, did not receive any compensation. ${ }^{53}$

The issue of compensation is pending as the bus owner has applied against the compensation order of Tk 10 lakh. Titumir college student Rajib lost his right arm through a road accident in Dhaka and died in the hospital. The High Court directed the BRTC and swajan pribahan to bear all the court's treatment cost also issued a rule asking the bus owners to explain why they should not be directed to give TK. one crore to Rajib Hossain as compensation. The writ petition seeking crore of TK. in compensation for Rajiv's death has also been postponed for the third time. Another write petition was filed on behalf of victim Rassel, who lost his leg due to being injured by a luxury bus coach of Greenline transport. ${ }^{44}$ On 12 March 2019, the High Court directed Green Line Transport to pay Tk. 50 lakh to the Rasel Sarker two weeks. ${ }^{55}$ The Green Line bus company has finally paid Tk. 5 lakh to the victim, and the court has ordered to pay the remaining Tk. 45 lakh within a month. At the same time, the Transport company has been asked to bear the cost of treatment of Rasel Sarker. Therefore, around a year have gone by, and Rasel hasn't received any amount of compensation.

${ }^{50}$ SC orders company to compensate victim's family, The Daily observer, 16 April,2017, Available at:https://www.observerbd.com/2016/04/16/146874.php

${ }^{51}$ M.M Jaman, 'Family yet to get compensation despite apex court order 'The New Age, 22jun, 2017, Available At: - http://www.newagebd.net/article/18717/family-yet-to-get-compensation-despite-apex-court-order-

52 P.P Chowdhury, ROAD SAFETY, Right to redress, The Daily Srat, 15 March, 2019, Available At:https://www.thedailystar.net/star-weekend/news/right-redress-1714576

53 A.R Rabbi, Suprovat bus driver killed Abrar while fleeing accident spot,Dhaka tribune, $21 \mathrm{March}$, 2019, Avaiable at:- https://www.dhakatribune.com/bangladesh/dhaka/2019/03/21/suprovat-busdriver-killed-abrar-while-fleeing-accident-spot

${ }^{54} \mathrm{HC}$ gives Green Line till 22 May to pay Rasel's compensation, Dhaka Tribune, 15May, 2019, Available At:- https://www.dhakatribune.com/bangladesh/court/2019/05/15/hc-orders-green-lineparibahan-to-pay-compensation-by-may-22

${ }^{55}$ Pay Tk 5m to bus accident victim Russell Sarkar, says top court, Bdnews.24.com, 31 March, 2019, Available At:- https://bdnews24.com/bangladesh/2019/03/31/pay-tk-5m-to-bus-accident-victim-rasel-sarkar-says-topcourt 
Although the High Court has ordered compensation along with the rules, those cases have been continuing for years. ${ }^{56}$

Several lawyers and legal scholars urge that when the concerned people delay carrying out the court decision, the case will have to be filed against them in contempt court. The final judgment of the High Court of compensation must be executed. ${ }^{57}$ Therefore, in the absence of fair justice or execution of court judgment encourage road accident mostly.58 Moreover, the country's government is responsible for controlling road accidents and ensuring the right of road safety for the citizen of the country and it one of the fundamental elements of good governance. 59

\section{CONCLUSION}

Road safety is correlated with achieving other sustainable development goals such as advancing transport productivity with universal access, mitigating climate change, and reducing local air and noise pollution. Therefore, to achieve regional and global trade facilities and connectivity, network productivity, global accessibility, and decarburization should be placed in the organizational strategy's first row. These sustainable mobility goals are crucially interrelated. An integrated policy framework with targeted safety investment strategies must negotiate with Bangladesh's complex strategic plan (WBG 2019a). Good practice of road safety programs in highincome countries over the past five decades has convincingly demonstrated the prevention of road crash fatalities and injuries and their devastating burden substantially be avoided.

Considerably, Bangladesh can improve its road safety performance over the coming decades. As per the World Bank's initiatives, road safety in the country can be reviewed by the authority regarding the progress being made, including road safety management, safe roads and mobility, safe vehicles and road users, and post-crash response. They were introducing more sustainable and environment-friendly modes of transportation, increasing vehicle safety and safe road and transport for all, including women and children, with stringent safety requirements for the procurement of sispitransport services. Secure speed management with infrastructure in cities and potential safety gains from new technologies should be initiated. (Government Offices of Sweden, WHO, 2019). Legal and judicial role need to be implemented properly as the rule of law has been absent for a long time. The amount of crime and punishment has been updated. However, the passengers' interest, drivers, and other related persons have not been taken into account to

\footnotetext{
${ }^{56}$ Alam, Shayeeka Binte, and Shamma Tasneem. "Improving Sustainable Pedestrian Facilities in Congested Urban Areas Adapting Breeam Assessment: A Case of Dhaka, Bangladesh." Asian Journal of Applied Science and Engineering 7, no. 1 (2018): 7-20.

${ }^{57}$ Chowdhury, Md Shoaib. "Public Transport in Dhaka: Organizational, Funding, and Financing Issues for Sustainable Development." In ICSI 2014: Creating Infrastructure for a Sustainable World, pp. 349-359. 2014.

${ }^{58}$ https://www.prothomalo.com/bangladesh/article/1627292/নিরাপদ-সড়কের-সঙ্গে-ন্যায়বিচারের-সম্পর্ক-রয়েছে

${ }^{59}$ ibid, according to Sultana Kamal Sultana Kamal ( a Bangladeshi lawyer and human rights activist). She serves as the Executive Director of Ain o Salish Kendra, a civil rights organization.
} 
implement the legal mechanisms properly. To this extent, the proper implementation of legislation would enhance the positive changes in disciplining Dhaka's road transportation system.

\section{REFERENCES}

A.A.Haider, Traffic jam: The ugly side of Dhaka's development The Daily Star,May,13,2018, Avaiable At:- https://www.thedailystar.net/opinion/society/traffic-jam-the-ugly-side-dhakasdevelopment-1575355

A.H.Rahbar, road Transport Act 2018 - details, repercussions, reactions, The Daily Star, November, 6, 2019, Avaiable At:- https://www.thedailystar.net/shift/news/road-transport-act2018-details-repurcussions-reactions-1823818

A.R Rabbi, Suprovat bus driver killed Abrar while fleeing accident spot,Dhaka tribune, 21 March 2019, Avaiable

at:https://www.dhakatribune.com/bangladesh/dhaka/2019/03/21/suprovat-bus-driver-killedabrar-while-fleeing-accident-spot

Ahmed, Bayes. "Contemporary issues and priorities in addressing the road safety problems of Dhaka metropolitan area, Bangladesh." Journal of Bangladesh Institute of Planners 6 (2013): 103-118.

Ahsan, H. M., M. A. Raihan, M. S. Rahman, and N. H. Arefin. "Reporting and recording of road traffic accidents in Bangladesh." In 4th annual paper meet and 1st civil engineering congress, pp. 22-24. 2011.

Alam, Shayeeka Binte, and Shamma Tasneem. "Improving Sustainable Pedestrian Facilities in Congested Urban Areas Adapting Breeam Assessment: A Case of Dhaka, Bangladesh." Asian Journal of Applied Science and Engineering 7, no. 1 (2018): 7-20.

Banik, B. K., M. A. I. Chowdhury, E. Hossain, and B. Mojumdar. "Road accident and safety study in Sylhet Region of Bangladesh." Journal of Engineering Science and Technology 6, no. 4 (2011): 493-505.

Biswas, S. K. "Road Traffic Injuries: an Emerging Problem in Bangladesh." Faridpur Medical College Journal 7, no. 1 (2012): 5-5.

Chowdhury, Md Shoaib. "Public Transport in Dhaka: Organizational, Funding, and Financing Issues for Sustainable Development." In ICSI 2014: Creating Infrastructure for a Sustainable World, pp. 349-359. 2014.

Hoque, M. M. "Road planning and engineering for promoting pedestrian safety in Bangladesh." In ROAD ENGINEERING ASSOCIATION OF ASIA AND AUSTRALASIA (REAAA) CONFERENCE, 10TH, 2000, TOKYO, JAPAN. 2000.

Hoque, M. M., J. Bin Alam, and K. M. N. Habib. "Road safety issues and initiatives in Bangladesh: the context of regional significance." Publication of: ARRB Transport Research, Limited (2003).

Hoque, M. M., S. Hossain, S. Islam, and M. A. Rahman. "Safe system for sustainable pedestrian safety in Bangladesh." In Australasian Road Safety Research Policing Education Conference, 2013, Brisbane, Queensland, Australia. 2013.

Hoque, M., Smith, G., \& Mahmud, S. M. (2011). Safer roads in Bangladesh: addressing the challenges of road infrastructure safety and linear settlements. In 24th World Road Congress World Road Association (PIARC). 
Hoque, Mazharul, Sohel Mahmud, Arefin Siddiqui, and Chowdhury Kawsar. "Road safety in Bangladesh and some recent advances." In Proceedings of the Road Safety on Four Continents Conference, vol. 14, pp. 12p-12p. Conference Sponsor, 2007.

Hoque, Md Shamsul, Shah Md Muniruzzaman, and S. N. Ahmed. "Performance evaluation of road safety measures: a case study of the dhaka-aricha highway in bangladesh." Transport and communications bulletin for Asia and the Pacific74 (2005): 33-56.

Hosain Zakir, 'How can we fix the world's worst traffic?' Dhaka tribune, 23, May,2019,Avaiable at: https://www.dhakatribune.com/opinion/op-ed/2019/05/23/how-canwe-fix-the-world-s-worst-traffic.

Ishtiaque, Ahmed, and Bayes Ahmed. "Urban road accidents in Dhaka, Bangladesh." (2013).

Mamun Sohel, Road Transport Act, 2018 goes into effect on Friday: BRTA not yet prepared to implement new traffic law, November, 1, 2019 Avaiable At:https://www.dhakatribune.com/bangladesh/2019/11/01/road-transport-act-2018-goesinto-effect-on-friday-brta-not-yet-prepared-to-implement-new-traffic-law

Maniruzzaman, K. M., and Raktim Mitra. "Road accidents in Bangladesh." IATSS research 29, no. 2 (2005): 71.

Mannan, Mohammed Shafiqul. "Road accidents in metropolitan Dhaka, Bangladesh." IATSS research 23, no. 2 (1999).

N.F.Antara, Why can't we stop traffic accidents in Dhaka? 10 June, 2018, Available at: https://www.dhakatribune.com/bangladesh/dhaka/2018/06/10/why-can-t-we-stop-trafficaccidents-in-dhaka

P.P Chowdhury, ROAD SAFETY, Right to redress, The Daily Srat, 15 March, 2019, Available At:- https://www.thedailystar.net/star-weekend/news/right-redress-1714576

Rahman, M. "Road accidents in Dhaka, Bangladesh: How to provide safer road?." In Proceedings of the Road Safety on Four Continents Conference, vol. 14, pp. 15p-15p. Conference Sponsor, 2007.

Rahman, Sonia. "Development of an accident prediction model for intersections of Dhaka city, Bangladesh." International Journal of Computer Applications 47, no. 16 (2012).

Report byBrace Institute of Government and Development, Avaiable at: http://www.brac.net/road-safety-programme

SAJJAN, MIRA. "Compensations For Death-Change In Approach Is Needed In Bangladesh."

Sufian, Abu Ahmed, Sakib Mahmud Khan, Ishtiak Ahmed, Sababa Islam, and Niloy Saha. "Safety analysis: observed deficiencies in existing transportation system of Bangladesh." International Journal of Urban Planning and Transportation 27, no. 1 (2016) 